\title{
Wisata Minat Khusus sebagai Alternatif Pengembangan Pariwisata di Kabupaten Bangli
}

\author{
I Wayan Wiwin \\ Program Studi Industri Perjalanan Jurusan Pariwisata Budaya \\ Fakultas Dharma Duta IHDN Denpasar \\ wiwinkayoan@gmail.com
}

\begin{abstract}
The special interest tourism has become the current tourism trend where special interest tourism is done to avoid mass tourism in other words special interest tourism is one of an alternative tourism. Special interest tourism that became a new phenomenon in the world of tourism became one of the demands for the providers of tourist services. The motivation of tourists in finding something new and having a quality tourist experience leads to increased demand for special interest tourists. Bangli regency is one of the areas in Bali that has a diverse range of potential tourist attractions of special interest, such as: Bali Woso Camp Agro and Culture, The Ayodya Oemah Strawberry, Anjungan Tukad Melangit (ATM) Antugan, N'jung Bali Camp Songan, Tukad Cepung Waterfall, and Twin Hill Bunutin.
\end{abstract}

Keynote : Special interest tourism, alternative tourism.

\section{Pendahuluan}

Pariwisata merupakan suatu hal yang penting bagi suatu negara. Dengan adanya pariwisata, suatu negara atau lebih khususnya pemerintah daerah dimana daya tarik wisata tersebut berada mendapat pemasukan dan pendapatan. Berkembangnya suatu daya tarik wisata akan menarik sektor lain untuk ikut berkembang pula karena produk-produknya diperlukan untuk menunjang sektor pariwisata tersebut, seperti sektor pertanian, peternakan, perkebunan, kerajinan rakyat, peningkatan kesempatan kerja dan lain sebagainya. Pulau Bali sebagai salah satu destinasi pariwisata di Indonesia memiliki keunikan yang khas bila dibandingkan dengan destinasi lainnya. Kekhasan budaya dan religinya mampu memikat wisatawan untuk berkunjung ke Pulau Bali.

Pulau Bali merupakan salah satu ikon pariwisata yang sudah dikenal oleh wisatawan baik wisatawan nusantara maupun wisatawan mancanegara. Hampir semua wilayah kabupaten di Bali memiliki potensi wisata yang dapat dikembangkan serta dikemas dengan baik untuk dapat menarik wisatawan. Salah satu kabupaten yang terletak di Provinsi Bali adalah Kabupaten Bangli. Kabupaten Bangli merupakan satu-satunya kabupaten di Bali yang tidak memiliki pantai atau dengan kata lain daerah Kabupaten Bangli berada di daerah pegunungan. Daya tarik wisata yang cukup dikenal di Kabupaten Bangli adalah Daya Tarik Wisata Khusus (DTWK) Kintamani, Desa Wisata Penglipuran dan Pura Kehen. Kabupaten Bangli terus berupaya untuk berinovasi mengembangkan potensi pariwisatanya, khusunya pengembangan wisata minat khusus yang berbasis pada pemberdayaan masyarakat lokal.

Wisata minat khusus telah menjadi trend pariwisata saat ini dimana wisata minat khusus ini dilakukan untuk menghindari pariwisata massal dengan kata lain wisata minat khusus adalah salah satu alternatif pariwisata. Wisata minat khusus yang menjadi fenomena baru di dunia pariwisata menjadi salah satu tuntutan bagi para penyedia jasa wisata. Motivasi wisatawan dalam mencari sesuatu yang baru dan mempunyai pengalaman wisata yang berkualitas menyebabkan meningkatnya permintaan bagi wisatawan minat khusus. Terutama bagi para penyedia jasa wisata yang ada di Pulau Bali dituntut agar memberikan inovasi yang baru, menarik dan berbeda dari biasanya. Di Pulau Bali wisata minat khusus identik dengan kondisi alam, budaya, sejarah serta kehidupan masyarakat lokal Bali. Dengan banyaknya permintaan wisatawan untuk menikmati pariwisata yang berbeda dengan yang lain saat berkunjung ke suatu destinasi pariwisata menuntut para penyedia jasa pariwisata untuk selalu berinovasi dan mencari hal baru dan menarik untuk kembali dapat menarik minat wisatawan berkunjung ke suatu daya tarik wisata. Dengan adanya permintaan pariwisata yang berbeda inilah masyarakat Bangli beserta pihak-pihak terkait terus melakukan inovasi dan memberikan ide-ide yang menarik untuk dunia pariwisata dengan tujuan untuk meningkatkan taraf kehidupan masyarakat melalui sektor pariwisata. Dengan adanya keterlibatan masyarakat lokal dalam pengembangan wisata minat khusus juga akan menyerap tenaga kerja dan lapangan pekerjaan baru bagi masyarakat setempat. 
Untuk itu diperlukan adanya suatu kajian tentang potensi wisata minat khusus yang sedang berkembang maupun memiliki prospek untuk dikembangkan di wilayah Kabupaten Bangli.

Pentingnya pengembangan pariwisata pada suatu daerah atau Negara sangat erat kaitannya dengan pembangunan perekonomian daerah atau Negara tersebut. Kita menyadari bahwa apabila suatu daerah industri pariwisatanya berkembang dengan baik, maka dengan sendirinya akan memberikan dampak positif bagi daerah itu, karena dapat menciptakan lapangan kerja yang cukup luas bagi penduduk setempat, serta dapat memberikan multiflier effect bagi pertumbuhan perekonomian di daerah tersebut.

Menurut Paturusi (2001) mengungkapkan bahwa pengembangan adalah suatu strategi yang dipergunakan untuk memajukan, memperbaiki dan meningkatkan kondisi kepariwisataan suatu objek dan daya tarik wisata sehingga dapat dikunjungi wisatawan serta mampu memberikan manfaat bagi masyarakat disekitar objek dan daya tarik wisata maupun bagi pemerintah. Disamping itu pengembangan pariwisata bertujuan untuk memberikan keuntungan bagi wisatawan maupun komunitas tuan rumah. Dengan adanya pembangunan pariwisata diharapkan mampu meningkatkan taraf hidup masyarakat melalui keuntungan secara ekonomi yang dibawa ke kawasan tersebut. Dengan kata lain pengembangan pariwisata melalui penyediaan fasilitas infrastruktur, wisatawan dan penduduk setempat akan saling diuntungkan. Pengembangan tersebut hendaknya sangat memperhatikan berbagai aspek, seperti aspek budaya, sejarah dan ekonomi daerah tujuan wisata. Berdasarkan pengertian diatas maka pengembangan adalah suatu kegiatan menata dan memajukan suatu obyek wisata untuk di kembangkan lebih layak.

Ismayanti (2009: 147) memaparkan bahwa daya tarik wisata merupakan fokus utama penggerak pariwisata di sebuah destinasi. Dalam arti, daya tarik wisata sebagai penggerak utama yang memotivasi wisatawan untuk mengunjungi suatu tempat. Potensi daya tarik wisata memiliki beberapa tujuan diantaranya; (a) memperoleh keuntungan baik dari segi ekonomi berupa devisa negara dan pertumbuhan ekonomi serta dari segi sosial berupa peningkatan kesejahteraan rakyat dan menghapuskan kemiskinan, b) menghapuskan kemiskinan dengan pembukaan lapangan pekerjaan dan mengatasi pengangguran, (c) memenuhi kebutuhan rekreasi masyarakat, sekaligus mengangkat citra bangsa dan memperkukuh jati diri bangsa, memupuk rasa cinta tanah air melalui pengusahaan daya tarik dalam negeri, (d) melestarikan alam, lingkungan dan sumberdaya, sekaligus memajukan kebudayaan melalui pemasaran pariwisata, (e) mempererat persahabatan antar bangsa dengan memahami nilai agama, adat istiadat dan kehidupan masyarakat.

Segala sesuatu yang menarik dan bernilai untuk dikunjungi dan dilihat disebut atraksi atau lazim pula di katakan daya tarik wisata. Atraksi-atraksi ini antara lain panorama keindahan alam yang menakjubkan seperti gunung, lembah, ngarai, air terjun, danau, pantai, matahari terbit, dan matahari terbenam, cuaca, udara dan lain-lain. Di samping itu juga berupa budaya hasil ciptaan manusia seperti monumen, candi, bangunan klasik, peningalan purba kala, musium budaya, arsitektur kuno, seni tari, musik, agama, adat-istiadat, upacara, pekan raya, peringatan perayaan hari jadi, pertandingan, atau kegiatan-kegiatan budaya, sosial dan keolahragaan lainnya yang bersifat khusus, menonjol dan meriah, (Pendit,2002.20).

Pengembangan daya tarik wisata alam sangat erat kaitannya dengan peningkatan produktifitas sumber daya alam dalam konteks pembangunan ekonomi, sehingga selalu dihadapkan pada kondisi interaksi berbagai kepentingan yang melibatkan aspek kawasan hutan, pemerintah daerah, aspek masyarakat, dan pihak swasta di dalam suatu sistem tata ruang wilayah. Kendala pengembangan obyek wisata alam berkaitan erat dengan: (a) Instrumen kebijaksanaan dalam pemanfaatan dan pengembangan fungsi kawasan untuk mendukung potensi obyek wisata alam; (b) Efektifitas fungsi dan peran obyek wisata alam ditinjau dari aspek koordinasi instansi terkait; (c) Kapasitas institusi dan kemampuan SDM dalam pengelolaan daya tarik wisata alam di kawasan hutan; dan (d) Mekanisme peran serta masyarakat dalam pengembangan pariwisata alam.

Perencanaan pengembangan suatu kawasan wisata memerlukan tahapan-tahapan pelaksanaan seperti: Marketing Research, Situational Analysis, Marketing Target, Tourism Promotion, serta pemberdayaan masyarakat dan swasta dalam promosi dan Marketing. (Syamsu.dkk, 2001). Lebih lanjut dijelaskan, untuk menjadikan suatu kawasan menjadi objek wisata yang berhasil haruslah memperhatikan faktor-faktor sebagai berikut; (1) Faktor kelangkaan (Scarcity) yakni: sifat objek/atraksi wisata yang tidak dapat dijumpai di tempat lain, termasuk kelangkaan alami maupun kelangkaan ciptaan. (2) Faktor kealamiahan (Naturalism) yakni: sifat dari objek/atraksi wisata yang belum tersentuh oleh perubahan akibat perilaku manusia. Atraksi wisata bisa berwujud suatu warisan budaya, atraksi alam yang belum mengalami banyak perubahan oleh perilaku manusia. (3) Faktor Keunikan (Uniqueness) yakni sifat objek/atraksi 
wisata yang memiliki keunggulan komparatif dibanding dengan objek lain yang ada di sekitarnya. (4) Faktor pemberdayaan masyarakat (Community empowerment). Faktor ini menghimbau agar masyarakat lokal benar-benar dapat diberdayakan dengan keberadaan suatu objek wisata di daerahnya, sehingga masyarakat akan memiliki rasa memiliki agar menimbulkan keramahtamahan bagi wisatawan yang berkunjung. (5) Faktor Optimalisasi lahan (Area optimalsation) maksudnya adalah lahan yang dipakai sebagai kawasan wisata alam digunakan berdasarkan pertimbangan optimalisasi sesuai dengan mekanisme pasar. Tanpa melupakan pertimbangan konservasi, preservasi, dan proteksi. (6) Faktor Pemerataan harus diatur sedemikian rupa sehingga menghasilkan manfaat terbesar untuk kelompok mnasyarakat yang paling tidak beruntung serta memberikan kesempatan yang sama kepada individu sehingga tercipta ketertiban masyarakat tuan rumah menjadi utuh dan padu dengan pengelola kawasan wisata.

Menurut Noer (2011) Aspek Perencanaan Pengembangan daya tarik wisata mencakup sistem perencanaan kawasan, penataan ruang (tata ruang wilayah), standarisasi, identifikasi potensi, koordinasi lintas sektoral, pendanaan, dan sistem informasi daya tarik wisata. Aspek Kelembagaan meliputi pemanfaatan dan peningkatan kapasitas institusi, sebagai mekanisme yang dapat mengatur berbagai kepentingan, secara operasional merupakan organisasi dengan SDM dan peraturan yang sesuai dan memiliki efisiensi tinggi. Aspek Sarana dan Prasarana yang memiliki dua sisi kepentingan, yaitu (1) alat memenuhi kebutuhan pariwisata, (2) sebagai pengendalian dalam rangka memelihara keseimbangan lingkungan, pembangunan sarana dan prasarana dapat meningkatkan daya dukung sehingga upaya pemanfaatan dapat dilakukan secara optimal. Aspek Pengelolaan, yaitu dengan mengembangkan profesionalisme dan pola pengelolaan daya tarik wisata yang siap mendukung kegiatan pariwisata dan mampu memanfaatkan potensi daya tarik wisata secara lestari. Aspek Pengusahaan yang memberi kesempatan dan mengatur pemanfaatan daya tarik wisata untuk tujuan pariwisata yang bersifat komersial kepada pihak ketiga dan membuka lapangan kerja bagi masyarakat setempat. Aspek Pemasaran dengan mempergunakan teknologi tinggi dan bekerja sama dengan berbagai pihak baik dalam negeri maupun luar negeri. Aspek Peran Serta Masyarakat melalui kesempatan-kesempatan usaha sehingga ikut membantu meningkatkan kesejahteraan masyarakat. Aspek Penelitian dan Pengembangan yang meliputi aspek fisik lingkungan, dan sosial ekonomi dari daya tarik wisata. Diharapkan nantinya mampu menyediakan informasi bagi pengembangan dan pembangunan kawasan, kebijaksanaan dan arahan pemanfaatan daya tarik wisata. Dalam rangka mengembangkan daya tarik wisata perlu segera dilaksanakan inventarisasi terhadap potensi daerah daya tarik wisata secara bertahap sesuai prioritas dengan memperhatikan nilai keunggulan saing dan keunggulan banding, kekhasan obyek, kebijaksanaan pengembangan serta ketersediaan dana dan tenaga. Potensi daerah tujuan wisata yang sudah ditemukan segera diinformasikan dan dipromosikan kepada calon penanam modal. Perlu dikembangkan sistem kemitraan dengan pihak swasta, lembaga swadaya masyarakat yang ada, dalam rangka mendukung optimalisasi pengembangan daya tarik wisata. Peranan pemerintah daerah dalam pengembangan daya tarik wisata sangat penting, dengan melaksanakan koordinasi, perencanaan, pelaksanaan serta monitoring pengembangan daya tarik wisata.

Berdasarkan pengertian diatas maka pengembangan adalah suatu kegiatan menata dan memajukan suatu obyek/daya tarik wisata untuk dikembangkan lebih baik.

Pariwisata akan dapat lebih berkembang atau dikembangkan jika suatu daerah terdapat lebih dari satu jenis objek dan daya tarik wisata (Marpaung, 2002). Berdasarkan Undang-Undang Republik Indonesia Nomor 10 tahun 2009 tentang kepariwisataan, daya tarik wisata adalah segala sesuatu yang memiliki keunikan, keindahan dan nilai yang berupa keanekaragaman kekayaan alam, budaya dan hasil buatan manusia yang menjadi sasaran atau tujuan kunjungan wisatawan. Menurut Yoeti (2006: 167) secara garis besar ada empat kelompok yang merupakan daya tarik bagi wisatawan datang pada suatu negara daerah tujuan wisata tertentu yaitu:

a. Natural Attraction, termasuk dalam kelompok ini adalah pemandangan (landscape), pemandangan laut (seascape), pantai (beaches) danau (lakes), air terjun (waterfall), kebun raya (national park), agrowisata (ogrotourism), gunung berapi (volcanos), termasuk pula flora dan fauna.

b. Build attraction, termasuk dalam kelompok ini antara lain bangunan dengan arsitektur yang menarik, seperti rumah adat, dan termasuk bangunan kuno dan modern seperti Opera Building (Sydney), WTC (New York), Forbiden City (China), atau Big Ben (London), TMII (Taman Mini Indonesia Indah) dan daya tarik buatan lainnya.

c. Cultural Attraction, dalam kelompok ini termasuk diantaranya peninggalan sejarah (historical Building), cerita-cerita rakyat (folklore), kesenian tradisional (traditional dances), museum, upacara keagamaan, festival kesenian dan semacamnya. 
d. Social Attraction, yang termasuk kelompok ini adalah tata cara hidup suatu masyarakat (the way of life), ragam bahasa (languages), upacara perkawinan, potong gigi, khitanan atau turun mandi dan kegiatan sosial lainnya.

Wilkinson, 1994 (dalam Pitana, 2009:69) menyebutkan jenis-jenis daya tarik wisata dibagi menjadi tiga macam, yaitu :

a) Daya Tarik Wisata Alam

Daya Tarik Wisata Alam adalah sumber daya alam yang berpotensi serta memiliki daya tarik bagi pengunjung baik dalam keadaan alami maupun setelah ada usaha budi daya.

b) Daya Tarik Wisata Sosial Budaya

Daya Tarik Wisata Sosial Budaya dapat dimanfaatkan dan dikembangkan sebagai objek dan daya tarik wisata meliputi museum, peninggalan sejarah, upacara adat, seni pertunjukan dan kerajinan.

c) Daya Tarik Wisata Minat Khusus

Daya Tarik Wisata Minat Khusus merupakan jenis wisata yang baru dikembangkan di Indonesia. Wisata ini lebih diutamakan pada wisatawan yang mempunyai motivasi khusus. Dengan demikian, biasanya para wisatawan harus memiliki keahlian. Contohnya: wisata petualangan (adventure), agrowisata, wisata spa, wisata belanja (shopping), wisata festival, wisata hobby, wisata sport, dan wisata spiritual.

Menurut Cooper (1993) unsur-unsur yang menentukan keberhasilan sebagai daerah tujuan wisata adalah : (a). Atraksi wisata (Attraction) yang meliputi atraksi alam dan buatan; (b). Kemudahan untuk mencapai akses (access) seperti ketersediaan transportasi lokal baik darat, laut maupun udara beserta sarana dan prasarana pendukungnya; (c). Kenyamanan (amenities) seperti kualitas akomodasi, ketersediaan restoran, jasa keuangan, keamanan serta jasa pendukung; (d). Jasa pendukung yang disediakan oleh pemerintah maupun swasta (ancilary service) termasuk didalamnya peraturan / perundang-undangan tentang kepariwisataan.

\section{Konsep Wisata Minat Khusus}

Menurut Anindita (2010) bahwa Wisata minat khusus petualangan dapat didefinisikan sebagai bentuk perjalan wisata yang dilakukan di suatu lokasi yang memiliki atribut fisik yang menekankan unsur tantangan, rekreatif, dan pencapaian keinginan seorang wisatawan melalui keterlibatan/ interaksi dengan unsur alam. Wisatawan yang terlibat dalam wisata minat khusus dapat di bagi menjadi 2 antara lain:

1) Kelompok Ringan (Soft Adventure): Kelompok yang melihat keterlibatan dirinya lebih merupakan keinginan untuk mencoba aktifitas baru, sehingga tingkat tantangan yang dijalani cenderung pada tingkat ringan sapai rata-rata.

2) Kelompok Berat (Hard Adventure): Kelompok yang memandang keikutsertaannya dalam kegiatan wisata minat khusus petualangan lebih merupakan sebagai tujuan atau motivasi utama, sehingga cenderung terlibat lebih aktif dan serius pada kegiatan yg diikuti. Kelompok ini cenderung mencari produk yang menawarkan tantangan di atas rata-rata.

Berdasarkan pengertian di atas, maka pengertian wisata minat khusus adalah suatu ketertarikan seseorang yang berkaitan dengan hobbi dimana wisatawan akan datang ke tempat wisata yang memiliki atribut fisik yang unik.

\section{Pariwisata Sebagai Alternatif}

Pemerintah harus mencari alternatif sektor ekonomi mana yang dianggap tepat untuk mempercepat penanggulangan kemiskinan dan masalah-masalah sosial ekonomi daerah. Salah satu sektor ekonomi yang dianggap cukup perspektif adalah sektor pariwisata. Sektor pariwisata diyakini tidak hanya sekedar mampu menjadi sektor andalan dalam usaha meningkatkan perolehan devisa untuk pembangunan, tetapi juga mampu mengentaskan kemiskinan. Hal ini sejalan dengan tujuan pengembangan pariwisata sesuai dengan Pasal 4 Undang-Undang RI Nomor 10 Tahun 2009 tentang Kepariwisataan, yang menyebutkan bahwa tujuan pengembangan pariwisata adalah :

a. Meningkatkan pertumbuhan ekonomi,

b. Meningkatkan kesejahteraan rakyat,

c. Menghapus kemiskinan

d. Mengatasi penganguran,

e. Melestarikan alam, lingkungan, dan sumber daya, 
f. Memajukan kebudayaan,

g. Mengangkat citra bangsa,

h. Memupuk rasa cinta tanah air,

i. Memperkukuh jati diri dan kesatuan bangsa,

j. Mempererat persahabatan antar bangsa.

Dengan demikian, sangat jelas bahwa peran sektor pariwisata sangat besar dalam pembangunan suatu daerah, terlebih Bali sebagai salah satu daerah di Indonesia yang memiliki beranekaragam potensi sumber daya pariwisata dan telah menjadi barometer pengembangan pariwisata nasional. Untuk itu diperlukan adanya usaha-usaha pengembangan potensi daya tarik wisata yang lebih atraktif dan inovatif agar mampu bersaing dengan daerah atau Negara lain di dunia.

\section{Pembahasan}

\section{Potensi Daya Tarik Wisata Minat Khusus di Kabupaten Bangli}

Berdasarkan hasil observasi dan wawancara, terdapat beragam potensi daya tarik wisata minat khusus yang tersebar hampir di seluruh wilayah di Kabupaten Bangli. Adapun potensi daya tarik wisata minat khusus tersebut adalah sebagai berikut.

\subsection{Bali Woso Camp, Pengotan}

Bali Woso Camp terletak di Dusun Delod Umah, Desa Pengotan, Kecamatan Bangli, Kabupaten Bangli. Bali Woso Camp berjarak sekitar 70 kilometer dari Bandara Internasional Ngurah Rai atau sekitar $50 \mathrm{~km}$ dari kota Denpasar. Dari Denpasar, perjalanan dapat ditempuh sekitar 1,5 jam dengan kendaraan roda empat. Baliwoso camp menyediakan penginapan berupa tenda doom. terdapat 10 tenda penginapan, 1 tenda komunal, dan 1 bale-bale pertemuan.

Terdapat dua rute yang dapat dipilih, jika ingin cepat sampai, kita dapat melewati sisi timur melalui Kota Gianyar. Atau jika ingin sekaligus berbelanja barang-barang seni, kita dapat melewati kawasan Ubud. Ketika masuk ke Desa Pengotan, suasana desa tradisional sudah terasa. Desa Pengotan memiliki jalan utama desa sepanjang kurang lebih 600 meter dan lebar 5 meter. Jalan ini lurus mengarah ke Pura Penataran Agung Pengotan, pura utama di desa itu. Di sisi kiri dan kanan jalan itu berdiri tembok yang memagari rumah-rumah warga. Pagar itu mengelilingi sebuah pekarangan yang dihuni satu keluarga besar. Angkul-angkul atau gerbang tradisional Bali menjadi pintu untuk masuk ke dalam pekarangan rumah. Warga Desa Pengotan menyebut tata ruang ini dengan istilah Jajar Wayang.

Berwisata di Desa Pengotan semakin lengkap dengan adanya Baliwoso Camping Site, sebuah penginapan berkonsep perkemahan. Para tamu akan bermalam di sebuah tenda berukuran 4 meter x 7 meter. Penginapan ini terletak sekitar $1 \mathrm{~km}$ dari pusat Desa Pengotan. Untuk menuju penginapan, para tamu melewati ladang-ladang milik warga desa. Jalan masuk itu hanya dapat dilalui satu mobil dan tanpa lampu jalan. Setiba di lokasi penginapan, para tamu akan dimanjakan keasrian berbagai jenis tanaman. Udara pun terasa sejuk karena lokasi ini berada di ketinggian 800 meter hingga 1.100 meter dari permukaan laut. terdapat 10 tenda yang dibangun di antara pepohonan yang rindang. Setiap tenda dapat digunakan 8-10 orang dengan tarif Rp 700.000 per orang per malam. Baliwoso dapat menampung maksimal 200 tamu. Saat akan tidur pada malam hari, hanya suara jangkrik yang terdengar. Bersiaplah juga karena udara dingin akan masuk ke dalam tenda dan membuat tubuh menggigil, terutama jika musim hujan. Selama menginap, tamu dapat mengikuti berbagai kegiatan yang diadaptasi dari kegiatan sehari-hari warga Pengotan. Staf Baliwoso yang sebagian besar penduduk Desa Pengotan akan menemani tamu beraktivitas di desa, misalnya membuat kerajinan seni, memainkan alat musik tradisional, atau berkebun. (Hasil observasi dan wawancara dengan pihak pengelola, 20 Agustus 2017).

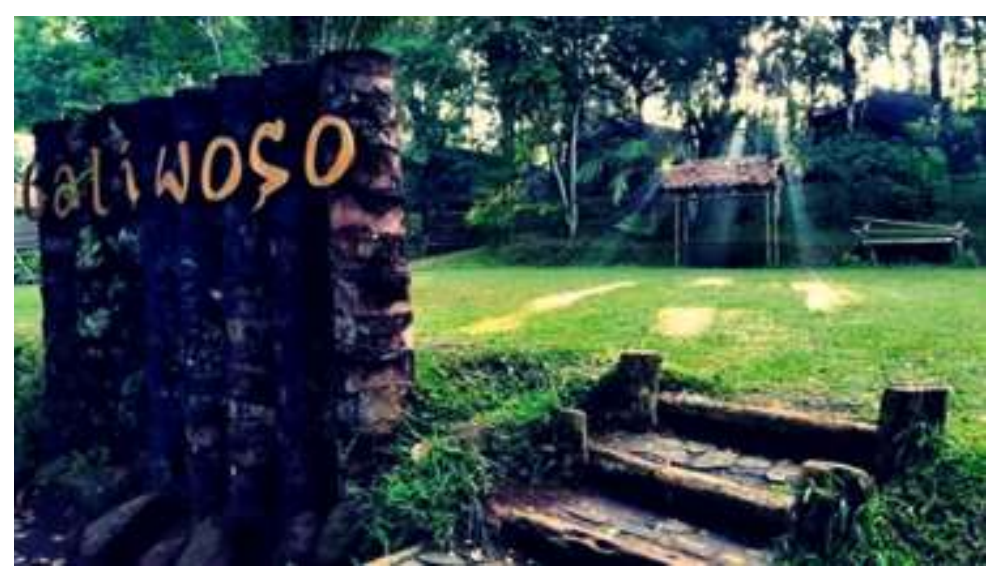


Foto 1 : Bali Woso Camp

Sumber : Dokumentasi penulis, 2017.

\subsection{The Ayodya Oemah Strawberry, Pengotan}

The Ayodya Oemah Strawberry berada persis di pinggir jalan Bangli - Singaraja, tepatnya di Desa Pengotan. Dapat dicapai dalam waktu 20 menit dari Kota Bangli. Sangat mudah dijangkau dan strategis untuk melepas lelah. Tempat yang "family style" ini menawarkan suasana garden cafe yang dikelilingi oleh perkebunan strawberry dengan sistem hidroponik. Di The Ayodya Oemah Strawberry pengunjung tidak saja bisa memesan minuman jus strawberry yang langsung dipetik dari kebunnya, tapi juga bisa mencoba beragam masakan dan minuman lainnya. Mereka juga menyediakan beragam fasilitas untuk anak-anak. Ada perosotan anak dari plastik yang diisi angin. Ada juga rumah pohon yang dibangun di pepohonan yang mengelilingi lapangan. Di sisi barat dibangun sebuah "love lock" yang berisi beragam "gembok cinta" dari pengunjung. Ada juga tempat foto selfie di ujung barat lapangan. The Ayodya Oemah Strawberry akan memanjakan pengunjung dengan fasilitas wisata yang sangat unik dan menarik khas suasana pedesaan. (Hasil observasi dan wawancara dengan pihak pengelola, 20 Agustus 2017).

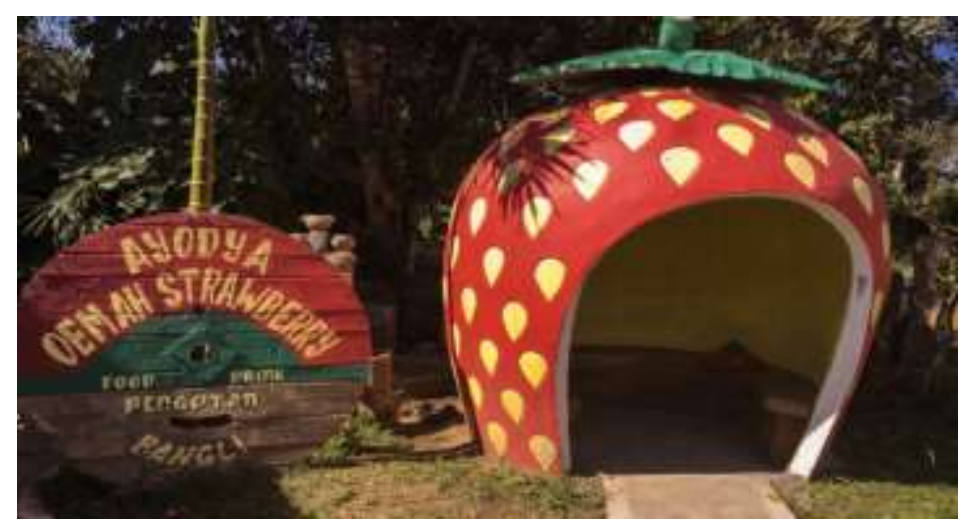

Foto 2 : The Ayodya Oemah Strawberry

Sumber : Dokumentasi penulis, 2017.

\subsection{N'jung Bali Camp, Songan}

Danau Batur menawarkan panorama yang seakan tidak ada habisnya. N'jung Bali Camp ini berada persis di pinggir Danau Batur sebelah barat, tepatnya di Banjar Dalem, Desa Songan. N'jung Bali Camp menawarkan pengalaman berkemah yang asyik di pinggir danau. Tentu saja pengunjung bisa datang ke tempat ini hanya untuk menikmati suasana hijau dan keindahan Danau Batur sambil melakukan aktifitas fishing dan bakar ikan yang sudah disediakan oleh pengelolanya. Pengunjung dapat menyewa tenda dengan segala segala perlengkapannya mulai dari harga Rp. 150.000 per tenda sesuai ukurannnya.

Sebenarnya tempat ini awalnya bukanlah tempat wisata melainkan sebuah lahan milik petani lokal yang tidak terurus dan kemudian agar tidak mubadzir tempat ini di kembangkan dan di renovasi sehingga menjadi sebuah tempat yang indah. Hanya dalam waktu kurang lebih satu tahun, seorang pemuda anak dari pemilik lahan yang akrab dipanggil Komang mulai mengembangkan lahan yang seluas 2500 meter per segi dimulai dari membangun bangunan gazebo dan penataan landscape dengan mempertahankan konsep alami. Meskipun banyak kendala namun Komang tidak putus asa dan pada akhirnya tempat ini menjadi sebuah wisata yang sangat menarik dan ramai pengunjung. Melalui media sosial N'jung Bali Camp Songan ini mulai dikenal orang dan membuat penasaran. Disini pengunjung juga bisa menemukan fasilitas lengkap dan mudah seperti area parkir yang aman, warung makan yang menyediakan menu lezat dengan harga terjangkau, kamar mandi yang bersih, peralatan camping, tempat istirahat, dan lain sebagianya. (Hasil observasi dan wawancara dengan pihak pengelola, 20 Agustus 2017). 


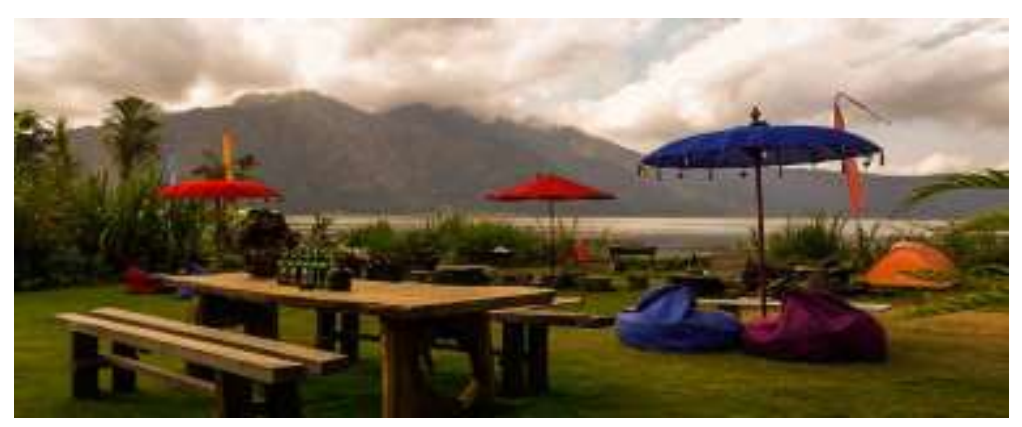

Foto 3 : The Ayodya Oemah Strawberry

Sumber : Dokumentasi penulis, 2017.

\subsection{Anjungan Tukad Melangit (ATM), Antugan}

Tempat ini lebih dikenal dengan nama ATM singkatan dari Anjungan Tukad Melangit. Adalah sebuah anjungan yang terbuat dari bambu menghadap ke arah selatan persis di atas Tukad Melangit. Itulah sebabnya disebut Anjungan Tukad Melangit.

Tempat wisata ini sedang ramai diunggah dan menjadi bahan perbincangan di media sosial sebagai salah satu tempat wisata favorit untuk wisata foto selfie (swa-foto) yang menjadi trend remaja saat ini, dan Anjungan Tukad Melangit sudah banyak dikunjungi oleh wisatawan, baik wisatawan lokal maupun maupun wisatawan asing.

Pada mulanya lokasi Anjungan Tukad Melangit ini hanya dibangun sederhana terbuat dari bahan bambu oleh beberapa orang pemuda setempat yang menjadikan tempat tersebut sebagai tempat berkumpul dan menghibur diri sekitar awal tahun 2016 yang lalu, namun lama-kelamaan setelah diunggah ke media sosial, hasil foto selfie di tempat ini mulai ramai dibicarakan oleh pengguna media sosial karena keindahan panorama alamnya yang mempesona, sehingga mulai ramai dikunjungi oleh wisatawan. Wisatawan yang berkunjung ke ATM hanya dikenakan donasi sebesar Rp. 5000 - 10.000 (lima ribu sampai sepuluh ribu rupiah) per orang dan dapat menikmati semua fasilitas yang tersedia seperti anjungan tempat foto selfie, ayunan, gazebo, tenda serta taman dengan pemandangan lembah alami yang sangat indah.

Wisata foto selfie sangat menjanjikan untuk terus dikembangkan sebagai daya tarik wisata minat khusus di kawasan Anjungan Tukad Melangit (ATM), hal ini terlihat dari semakin meningkatnya jumlah kunjungan wisatawan ke ATM serta banyaknya akun media sosial (seperti facebook, twiter, instagram) yang menggunggah foto selfie mereka di Anjungan Tukad Melangit.

Anjungan Tukad Melangit (ATM) terletak di Dusun Antugan, Desa Jehem, Kecamatan Tembuku, Kabupaten Bangli yang berjarak sekitar 6 kilometer arah timur laut dari pusat Kota Bangli, dan sekitar 50 kilometer dari Kota Denpasar yang dapat di tempuh dengan waktu kurang lebih 1,5 jam. (Hasil observasi dan wawancara dengan pihak pengelola, 27 Agustus 2017).

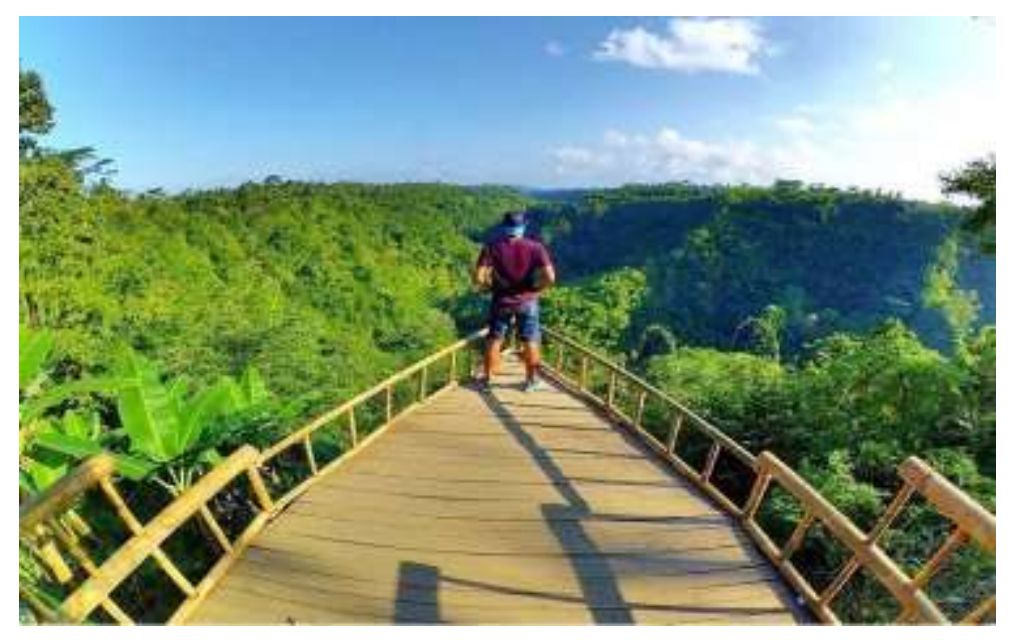

Foto 4 : Anjungan Tukad Melangit (ATM)

Sumber : Dokumentasi penulis, 2017.

\subsection{Tukad Cepung Waterfall, Tembuku}


Keindahan air terjun memiliki daya tarik tersendiri bagi wisatawan. Walaupun pulau Bali berukuran kecil tetapi memiliki banyak tempat wisata air terjun yang tidak kalah indah dan tentunya memiliki keunikan tersendiri. Lokasi air terjun Tukad Cepung berada di Banjar Penida Kelod, Desa Tembuku, Kecamatan Tembuku, Kabupaten Bangli, Bali. Dari kota Bangli hanya berjarak sekitar 8 km, sedangkan jika dari Kota Denpasar berjarak kira-kira 40 km. Dari Bandara Ngurah Rai menempuh jarak sekitar $50 \mathrm{~km}$ atau dengan waktu tempuh kira-kira 70 menit perjalanan dengan kendaraan bermotor.

Untuk mencapai lokasi air terjun ini pengunjung harus menuruni jalan yang berundak, menyusuri pinggiran kali, dan menuruni tebing dengan bebatuannya mirip seperti ngarai tersembunyi. Wisatawan juga harus menyelinap ke tengah-tengah diantara tebing yang menyerupai goa lantaran jalan yang sempit sebelum menemukan mencapai air terjun ini. Sepanjang perjalanan pemadangan alam sekitarnya tampak asri dengan rimbunnya pepohonan sekitar. Air terjun ini memiliki ketinggian sekitar 15 meter. Jika diperhatikan sekilas tampak air terjun ini jatuh dari langit karena disilaukan oleh cahaya matahari, sehingga tidak mengherankan kalau air terjun ini dikatakan sebagai air terjun dari langit. Untuk menikmati air terjun ini kita harus membayar donasi secara sukarela (tidak ada tarif masuk) yang akan digunakan untuk pengelolaan tempat ini. Air terjun ini dikelola oleh kelompok pemuda desa setempat. Begitu pengunjung sampai diparkiran, akan disabut oleh anak-anak muda dari banjar setempat dengan ramah serta menunjukan lokasi air terjun Tukad Cepung.

Wisatawan yang datang ke air terjun Tukad Cepung ini kebanyakan wisatawan lokal. Tidak hanya dinikmati oleh wisatawan lokal, terkadang juga terlihat wisatawan mancanegara yang ikut menikmati pesona air terjun ini. Selain bisa menikmati indahnya air terjun pengunjung juga bisa membersihkan diri (melukat) di area ini, karena tidak jauh dari lokasi air terjun terdapat tempat penglukatan (penyucian diri) yang disebut Petirtaan Nawa Tirta. (Hasil observasi dan wawancara dengan pihak pengelola, 27 Agustus 2017).

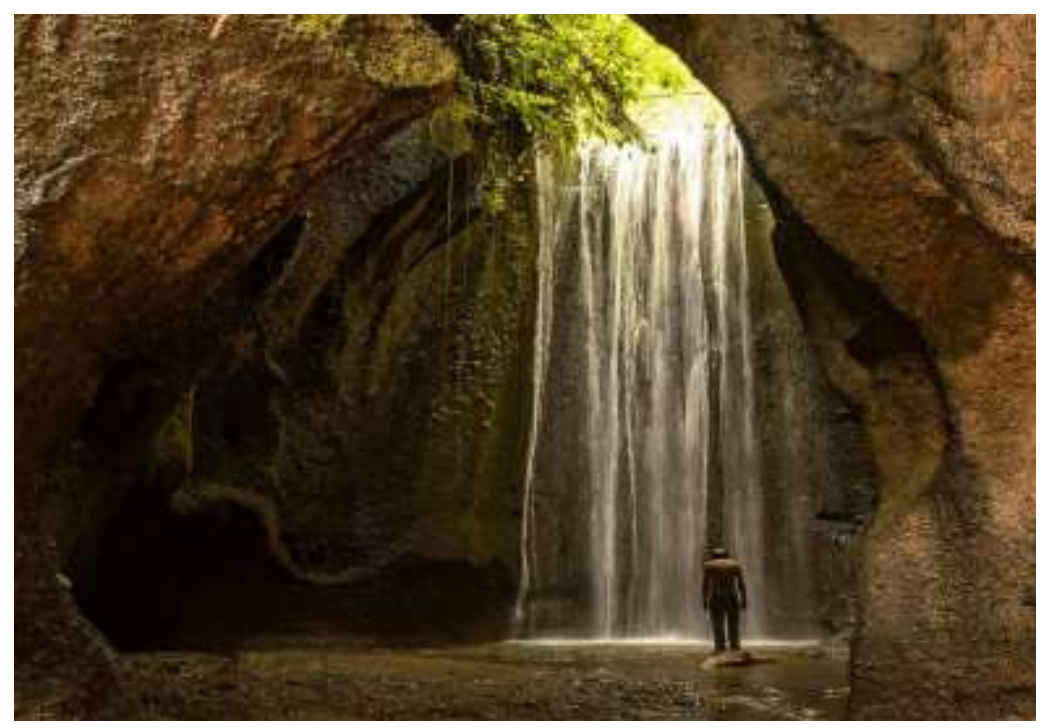

Foto 5 : Tukad Cepung Waterfall

Sumber : Dokumentasi penulis, 2017.

\subsection{Twin Hill, Bunutin}

Menikmati pemandangan dari ketinggian memang memberi kesan berbeda, membuat jarak pandang seseorang menjadi lebih luas. Misalkan saja Twin Hill, wisata alam di Banjar Guliang Kawan, Desa Bunutin, Bangli, tepat di perbatasan antara Kabupaten Gianyar dan Kabupaten Bangli. Twin Hill, tempat yang strategis untuk menikmati pemandangan alam Pulau Bali yang eksotis nan indah.

Dari puncaknya, pengunjung bisa menyaksikan hamparan sawah, pemukiman, hingga laut. Bahkan samar-samar, Pulau Nusa Penida yang berada di seberang lautan juga bisa dilihat. Inilah yang menjadi daya tarik Twin Hill sebagai tempat wisata. Bukit ini sesungguhnya bernama Bukit Batu Madeg. Twin Hill adalah cara masyarakat setempat menyebut Bukit Batu Madeg dan Bukit Jati yang letaknya berdekatan, terlihat seperti sepasang bukit kembar. Bukit ini juga memiliki sebutan yang kata anak muda sekarang 'kekinian' yaitu Bukit Selfie, merujuk pada fungsi bukit yang sering digunakan untuk berfoto selfie.

Saat hari cerah, pengunjung dapat menyaksikan matahari terbit. Selain itu keagungan Gunung Agung pun bisa dilihat dari puncak Twin Hill. Pengunjung juga dapat melihat keindahan 
hamparan sawah yang terkesan memiliki gradasi sebab ada yang padinya masih menghijau, ada yang mendekati masa panen, hingga sawah yang sudah didominasi warna kuning.

Agar pengunjung dapat menyaksikan pemandangan alam nan indah tersebut, pengelola telah menyiapkan beberapa fasilitas. Mereka membangun anjungan yang langsung mengarah ke pemandangan laut. Bentuknya memang masih sederhana, hanya menggunakan kayu. Meja dan kursi tempat duduk juga dapat dimanfaatkan oleh pengunjung. Twin Hill dihiasi dengan sejumlah umbul-umbul dan topi petani tradisional (capil) warna-warni untuk membuat pemandangan semakin indah. Tempat ini pun sangat cocok dikunjungi bersama teman ataupun keluarga. Bersantai di alam terbuka tentu saja bisa menjadi sarana refreshing yang cocok untuk melepas penat. Rindangnya pohon serta semilir angin sepoi membuat pengunjung semakin betah berada di tempat ini.

Meskipun berada di ketinggian bukit, namun untuk sampai ke puncak tidak memerlukan waktu yang lama. Ketinggian bukit ini dari tempat parkir kendaraan barangkali tidak sampai 30 meter. Menikmati pemandangan indah ini tidak perlu menguras dompet terlalu dalam. Pengelola hanya memberlakukan sumbangan sukarela untuk menikmati Twin Hill ini. Selain sebagai tempat bersantai dan lokasi foto yang instagramable, Twin Hill juga memiliki potensi wisata outbond. Bagi yang membawa hammock (kasur gantung), pengunjung bisa mengaitkan hammock di antara dua pohon dan bersantai di atasnya. Aktivitas tracking dan camping pun menjadi kegiatan yang potensial dilakukan di Twin Hill. Jalur bukit yang tidak begitu terjal membuat tracking di jalur Bukit Batu Madeg cocok untuk dilalui.

Menjelajah Bukit Batu Madeg, pengunjung bisa melihat keunikan Pura yang ada di puncak Bukit Batu Madeg. Di bukit ini terdapat lahan yang cukup memadai untuk mendirikan tenda. Akan tetapi untuk tracking dan camping, pengunjung harus menunggu beberapa waktu. Pengelola masih membangun beberapa sarana pendukung agar potensi wisata outdoor ini lebih aman dan nyaman. Saat ini fasilitas pariwisata yang ada di Twin Hill sepenuhnya dikelola oleh Kelompok Sadar Wisata Guliang Kawan, Desa Bunutin. (Hasil observasi dan wawancara dengan pihak pengelola, 3 September 2017).

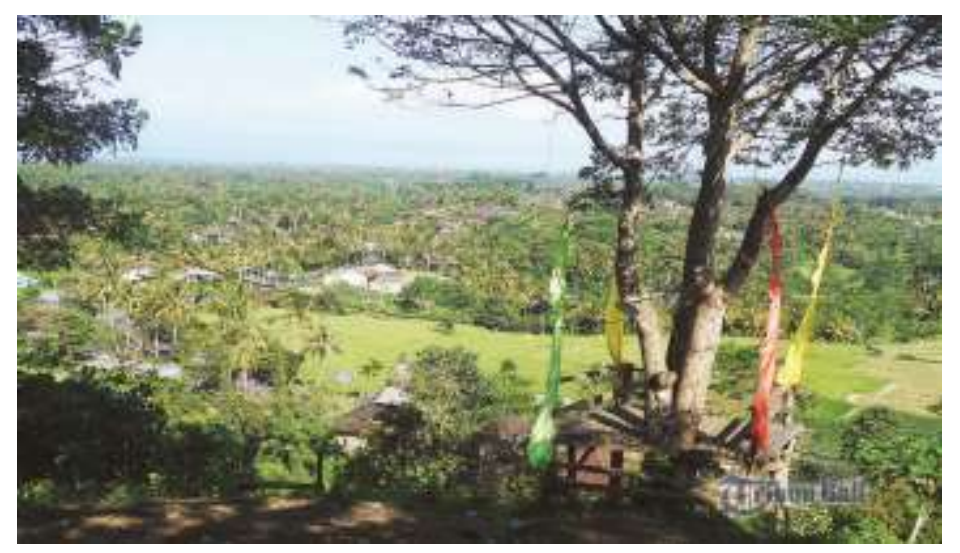

Foto 6 : Twin Hill

Sumber : Tribun Bali, 2017.

\section{Penutup}

Wisata minat khusus merupakan jenis wisata alternatif yang mendukung upaya pengembangan produk wisata yang ramah lingkungan serta berkelanjutan. Jenis wisata ini menjadi pilihan di tengah kejenuhan produk wisata masal (mass tourism) selama ini yang cenderung monoton, kurang atraktif, serta berdampak negatif terhadap lingkungan. Wisata minat khusus (special interest) akan menawarkan berbagai pilihan alternatif sesuai minat dan ketertarikan wisatawan yang akan memberikan suguhan yang berbeda dan pengalaman tersendiri bagi wisatawan.

Kabupaten Bangli memimiliki beraneka ragam potensi wisata minat khusus yang sangat potensial untuk terus dikembangkan guna meningkatkan perekonomian masyarakat lokal, membuka lapangan pekerjaan serta meningkatkan pendapatan asli daerah (PAD) untuk membiayai pembangunan daerah. Pengembangan wisata minat khusus tersebut tentunya akan memberikan alternatif pilihan yang beragam bagi wisatawan sehingga dapat menjadikan Kabupaten Bangli mampu bersaing dengan kabupaten lain di Bali, dan diharapakan tidak terjadi lagi ketimpangan dalam pendapatan hasil pembangunan pariwisata Bali. Kabupaten Bangli tidak lagi semata-mata hanya mengandalkan kawasan Kintamani sebagai satu-satunya tumpuan pengembangan pariwisata, terdapat beraenaka ragam potensi wisata yang tersebar di seluruh wilayah Kabupaten 
Bangli, mulai dari potensi alam, budaya, maupun buatan yang tentunya memerlukan usaha dan dukungan dari pemerintah, pihak swasta dan masyarakat lokal untuk memaksimalkan pemanfaatan potensi wisata tersebut.

\section{Daftar Pustaka}

Anonim, 2016. Informasi Kepariwisataan Kabupaten Bangli 2016. Bangli : Dinas Kebudayaan dan Pariwisata Kabupaten Bangli.

, Undang-Undang Nomor 10 Tahun 2009 tentang Kepariwisataan.

, 2001. Kamus Besar Bahasa Indonesia (Jilid III). Jakarta: Balai Pustaka.

Anindita. 2010. Potensi Pengembangan Wisata Minat Khusus. Jakarta: Grasindo.

Basrowi \& Suwandi. 2008. Memahami Penelitian Kualitatif. Jakarta: Rineka Cipta.

Craib, Ian. 1986. Teori-Teori Sosial Modern dari Parsons sampai Habermas. Jakarta: CV Rajawali.

Faisal, Sanafiah. 2001. Format-Format Penelitian Sosial. Jakarta: PT. Raya Grafindo Persada.

Geriya, Wayan. 1996. Pariwisata dan Dinamika Kebudayaan Lokal, Nasional, Global. Denpasar: Upada Sastra.

Ismayanti. 2009. Pengantar Pariwisata. Jakarta: Grasindo.

Kusmayadi, E. S., 2000. Metodelogi Penelitian dalam Bidang Kepariwisataan. Jakarta: PT Gramedia Pustaka Utama.

Marpaung, H. 2002. Pengetahuan Kepariwisataan Edisi Revisi. Bandung : Alfa Beta.

Marzuki. 1977. Metodelogi Riset. Yogyakarta: BPFE-UII.

Paturusi, Samsul A, 2001, Perencanaan Tata Ruang Kawasan Pariwisata, Materi Kuliah Perencanaan Kawasan Pariwisata, Program Pasca Sarjana Universitas Udayana Denpasar, Bali.

Pendit, Nyoman S. (2002). Ilmu Pariwisata Sebuah Pengantar Perdana. Jakarta: PT. Pradnya Paramita.

Pitana, I Gde. 1999. Pelangi Pariwisata Bali. Denpasar: Bali Post. 2005. Sosiologi Pariwisata. Yogyakarta: ANDI.

Smith, August W. 2001. The Quality Audit Handbook. Wisconsin: ASQC.

Sumadi, K. 2000. Kepariwisataan Indonesia Sebuah Pengantar. Denpasar: Sari Kahyangan.

Suwantoro, G. 2002. Dasar-Dasar Pariwisata. Yogyakarta: ANDI.

Syamsu, Yoharman. 2001. "Penerapan Etika Perencanaan pada kawasan wisata, studi kasus di kawasan Agrowisata Salak Pondoh, Kabupaten Sleman, Daerah Istimewa Yogyakarta". Jakarta: LP3M STP Tri Sakti, Jurnal Ilmiah, Vol 5. No. 3 Maret 2001.

Wardiyanta, 2006. Metode Penelitian Pariwisata. Yogyakarta: ANDI.

Yoeti, Oka A. 1996. Pengantar Ilmu Pariwisata. Bandung: Angkasa Paramita. 
Internet :

https://dawala.wordpress.com/2011/07/01/menginap-di-baliwoso-camp-menyatu-dengan-alamdan-budaya/

https://www.melalay.com/2016/10/09/ini-dia-tempat-baru-yang-lagi-hits-di-bangli/ 